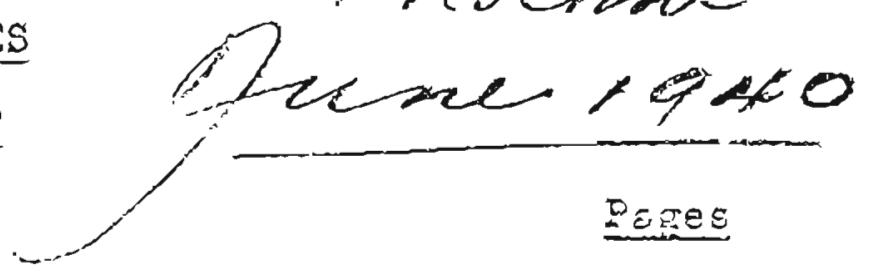

Alrske Gold Mountain Mines

(Alta Clalms)

$8-9$

Anne VIne Froepect (Ectvet. Olson ara Knuckolls)

5

Annette Island (Renewed lease proposals)

(Libe Claims Lone Wolf Nos. 1 and 2 examined b: Roehm)

Blue Jay Mine (Bert Libe)

Burchell Brothers Property

Cascaa Froperty (J1m Matusika)

14

Cracker Jack Property (Nok1okens)

13

Flagstaff Mine (Examined in company vith U.S. Rush) 10-12

Flora and Nellie Property (George Jarvis) 14

Free Gold Property (Freeburn, Petersor, et al) 2-3

Gold Standara Mine (John Folwarzny) 5

Hope rine (B. LeBrant) 13

Kesaan Gold Kine 12

Lone Jack Prospect (Ernest Steers ena associztes) 6

Miller Ledge and Lode Clalms (Novainey and Hollana) 7

Salt Chuok or Goodro Mine (Alaska Golö Metals Co.) 13

Shoenbar Property (Examined with Dr. Peterson) 14-1E Bonded to Thos. Drsyton

Siending Beaury Mining Co. Ind. 5

Thorne Arm Properties (Iãle) 9 


\section{HYDER PRECINCT}

Note re Rivereldo

\section{WRANGELL PRECINCT}

Bradileld Canal (Prospeciting reported being done by Anderson and Thygenson) 15

Brom and Kearsley Property

15-16

Coronation Island 


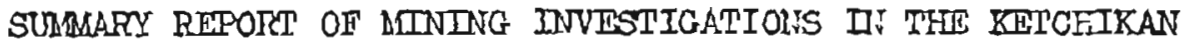 AND WRANGEIL, DISTRICTS AND ITINERARY OF J, C. ROEFM, ASSOCIATE ENGINEER \\ TO

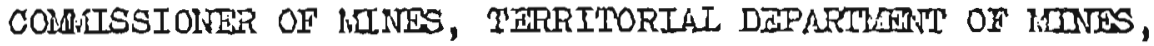 JUNEAU, ALASKA \\ May 24 to June 18, 1940.}

A total of 16 properties were examined, 14 of which ware situated in the Kotchikan district and 2 in the wangell distriot, from May 24 to Jure 18, 1940 .

The Ketchikan district as a phole, experienced ouring the lest year eeveral attempts at mining development, most of which have at the present time cersed. Of the total of ten active developments ouring last year, only four remain active thio spring. The causeg for these conditione bave been many, however, the main ceuses fell under headings familier to the mining industry such as misrepresentation, lack of officlent manegement, laok of knowledge of geological conditions, and the ever present oondition that goes along with the gbove, lack of capital. The most discouraging feature has been the closing down of the property of the Flagataf Minlug Company. So unisely has money been spent and Bo poor has been the managenent, even in the face of sound advice, that an onginoer sent by the major interests gave the pollowsing as a final conclugion in ils report:

"Recommendatione-Thet you cease operations at once and pooket your 1083. In this connection your legse provides that you con osabe operations for three months oach year. You might take advantage of this clause and endeavor to lnierast otherato pay gomething--even if in the future--for your equity."

- This only shows the result of placing ell the costs of poor (a management included in the total, whth construction and development oosts, d against an undeveloped prospect, assuming this prospeot to bo a proven

(mine, and to be produciag a profit. Thus this organization is nearly $j$ where it atarted thres years ago, faced with the necessity of hirling a capable man to manage and to do conglderable development work, two factors of which they heve been personally advibed, and nov, plus an allowence for improvements, the compeng is froed with a handicap of the total oum spent anounting to a reported figure of $\$ 160,000$. Of this emount, after an invostigation and an eveluation placed on all oquipment, expenses, labor and supplies, there is an amount of 43,000 unacoounted for and the compeny is at present in debt.

The Ketchiken district a a whole does show increased activity over prior years. A total of 1800 feet of underground development conalsting of drifts, shafts, raises and crosecuts have beon accomplishad during the pest yoar. A total of 14,000* tons of ore has elther beeit

*Approximate - awalt returns of Alaske Gold \& Metals Co.

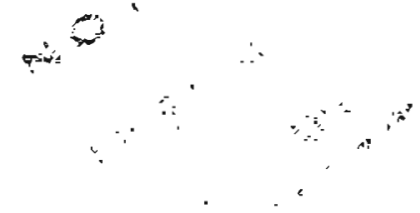


rililed or shipped during the last year. The outlook for this season is not at the present time as good as last year. Operetors have notloed an increase in prioes of comodities in Kotchikan. The war conditions W11 no doubt have an effect on the amount of outalde cap1tal. The promise of leasing portions of Annette $I_{B}$ land, if and when such is done, may leed to the development of promialng prospeots. The developments in Helm Bey heve shown considerable enlightenment as to the typo, size, and shepe of the orebodies. The fault problem on the Free fold or

Kagean Cold property on Barris Creek has been solved to the extent that the apperent cross vein was only a eegment of the orlginal rein feulted on a binge type fault and the continuation of the orobody loakted underground under normal $d i p$ and strike conditions and the vein unfauited and In plaoe looted on the surfaco. Th1s latter information, brought about by the last yoar of development, is enoouraging and may load to moro development and a greater production.

The following is a sumary of conditiong according to itinerary:

May 24-27 - En route Juneau to Ketoh1kan and Holm Bay.

The Free cold property, looated along the wost shore of Feim $k x-19-123$

Bay, and adjolning the cold Standard property on the north, wes optloned
to J. L. Freaburm on January 5, 1940 for a period of three years wth a purchase prioe of $\$ 50,000$, the latter to be peld fram royaltios on ress production. Four men were employed from January 15 to March 14, and since then one man hes been retalned on the property dolng assessment work. A totel of 208 foet of development mes done underground suring

U the above parlod. Thle mork sonsisted of two drifts driven off the matn Free cold orossout tunnel at a polnt 250 feet in from the portal. At this point a mineralized and quartz interoelated drag fold formed by faulted block movement in reenstone achist has formed a zone approximately 20 feet in whath megsured along the croseout, phloh contains gold values. Drifts were started, both north and south, on thls zone. The drift north was extended nearly 40 feot and the ralues stopped in a length less than 30 peet. Thence a crossout wes ariven to the footwall from a point 20 feet from the start of the drift. Since this crosscut shows mineralization, and various folded quartz stringers, channel samples Nos. 806, 807 and 808 were teken eoross 5-foot widths beginning 5 feet back from the face. Thence a drift was driven on the south aide following a post mineral feult a distance of 90 feot, thence a 40 -foot crossout was driven to the east, and thenoe a short drift off the orossout. Samples Noe. 801 to 805 were taken across 5-foot waths along the 40-foot crosscut. 
The ore zone has a strike of r.. 10 to $200 \mathrm{~W}$. With a dip of sohistosity averaging $45^{\circ}$ to the eagt, and a plunge along the line of gtrike which ranges from 29 to $32^{\circ}$ to the north. This lov degree plunge has not been taken into eccount, and accounts for, along wh the $45^{\circ}$ dip, the termination of velues in the drifts in esch direction both south and north, since they heve been driven on a horizontal and have passed through the extremlties of the ore. In other words, the north drift has pessed in its extremity over the orebody and the south drift hes passed into the footwall due to following the post mineral fault and is under the orebody. Further, the small post mineral pault, whlch strikes nearly north and south and has a $60^{\circ} \mathrm{d} 1 \mathrm{p}$, outs the ore zone obliquely, has a movement of elther the haneing wall dorm or the footwell tibruat up, has oaused a few feet of dieplacement, and adds to the difficulty of obtalning the origlnal ahape and measurements of the orebody. Howerer, in comparing this orebody with the orebods at the Blue Jay mine, where as yet no post-mineral feult has been observed, its orlginal shape mas similer or the shape of a letter $S$ draw backwards, while the Blue Jay mine orebody has the ghape of a letter $s$. Both orebodles have formea on similar etructures and movement between blooks. Horrever, the movement as to walls on each orebody has be日n reversed. Both orebodies and along the alp both up and down in a small fold, one the reverse of the other. 0 These folds have been formed by pressure and movement along block walls fand to follow on the continuation of the ore moans to develop along the rake of the orebody.

in Mr. Homer Bradiond was in charge of operations for J. L. Fre日burn. Dr. Peterson of Ketchikan is also interested in the development. N'Their problems were taken up whth both Dr. Petergon and kr. Bredford. The present activity et the property is limited to the work of one man. i.. Otber development is uncertain. Ag a mattor of edvice, I elsgested surface - work in blasting off the tops or leached quartz outorops in all the outs such as the Mahoney out, etc. One trench after blasting away the surface waethered quartz began, showing assay values as shown on assay sheet of June 4, Ketchlkan Assay Offloe, marked Dr. Petersan Nos. I to 5, inclusive. These samples were taken by the workman over reported lengtha of 5 feet sach. Thus a continuation of this type of work wlll add to the value of the property. The number of gurface outcrops indicates there may be several srall ore shoots similar to the one describod in the crossout tunnel. Whether or not these orebodies will contain both commercial velues and quantities of ore depende upon further development.

A totel of four:men were amployed during the perlod of development underground from January 15 to Karch 14.

A sketch map was made of the oroagcut tunnel and the new developments. 


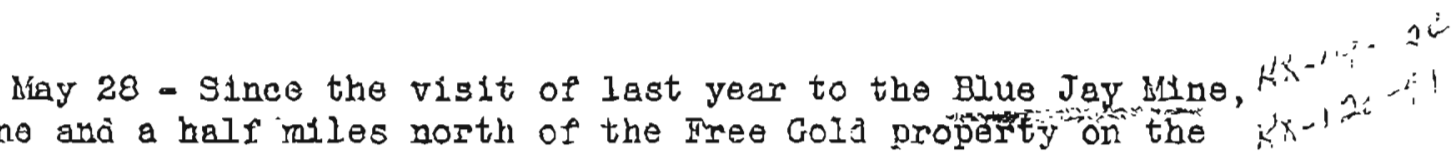
located one ard a half iniles north of the Free Gold property on the
west side of riolm Bay, a 25-tor mill has boen erected and a total of 300 tons of ore has been milled. Both mill and mine have been closed since Decerober 1, 1939. Preperations are being made to begin iniling within a rew days. This whil consist of mining and milling one shift with a gmell orew. Congiderable difflculty was experienced both in mining and miling. The uill heads were reported a ranging from six to seven dollars per ton. The conoentrate rat10 averaged $1-50$, whth concentrater valued at \$100 per ton. Congldereble trouble was experienced with the plates and a poor recovery was made, which resulted in operating at a loss for the above period. Furtber development in the mine oonsisted of an additional 15 feet of drift on the south end of the ore which followed a small atringer cutting. Into the footwil, one round into the banging well, If 10 feet back froin the south feos, and four ralses connecting with four N small stopes. These stopes are up respeotive $3530,25,20$ and 40 foet. The difficulty encountered in mining was due to not taking into consideration both rake and dip of the orebody. The flrst two ralses on the north end were through the ore at distgnces of 15 and 25 feet up. The other two raiseg on the southern portion topped the ore at 35 and 40 pert above the drift on the dip and due to the shape of the S-type orebody are in the footwall. Further, due to the nature of the ore zone not being confined to definite wall and the major portion of the ralues in the schist oombined in the pysite mineralization, consldergble low grade rock was broken and mined with the ore. The nature, shape, atp and plunge of the orebody was discussed with lir. Libe, owner. He intends to mine and mill on a small soale and posstbly sink on the ore.

A totel expenditure, 1ncluding cost of development, cost of mili and arection, plus tremay and bulldings, includtng a small assey office, was reported as amounting to nearly $\$ 50,000$. This amount has been well spent with considerable value to show. The fallure at milling was pertiy due to Mr. Libe's Illness during this period. Jur. Love, ongineer and intli man hired for the klaska Gold Mountain Mines, wes in charge during this latter perlod. All machinery is housed in the mill building which is well oonstruoted. Ore is trammod by hand to a $5^{\prime} \times 30^{n}, 3 / 4^{\prime \prime}$ rallroad rall grizzly, whth fines dropping to a 35-ton ore bin, and the cosrse is fed to a No. 3 Gibson Jaw cruaher. In the bottom of the ore bin a plunger type feeder, feeds a 25-ton Denver Iron Works bell mill. Four pound steel balls are fused and the ball mill hes a sooop feoder. The overflow of the ball mill goes to a spiral classifier with coarge matertal returming to the ball mill and flae pulp, 40-mesh, flows over analgam plates. Below the plates the flov runs over matting and thence over a Wilfley table. The actual capacity of this 25-toll mill was roported as ono ton per hour. The mill is powered by an $85 \mathrm{~K}$. 2. Cuniming diegel from a main shast line with unguarded belta and incluaing a Rex two-cylinder compressor, slngie stage. A lio-volt direct current vestinghouse generator, wich runs of the main sheft, is used for lights. The mill started September 2, 1939 and operated intermittentiy unt1l December 1, 1939. A total of six men were employed during this perlod. 
The property of the Sleoplng Beauty Mining Company, Inc., $x+i \sin x$ located north and adjolning the property of the Blue Jay lifua, was not visited. Since January, three man were reported buliding road iron the beach to the tunnel site, and at the preaent time were reported engaged in the building of two small bridges. A diesel engine and a double 8"xl2" atean compressor was moved from the beach to the tunnel site where en 18'232' oompressor house has been bullt. The amount of underground developinent was reported as conelating of two holes drilled in back of the old tunnel. The oompressor broke and 18 awatting repairs. There hes been conslderable controversy as to bow the road money hes been spent.

Thomag and Harr1s Burchell are prospecting along the shores of HeIm B8y. These two brothers are new-comers from Dellos, Texas.

4

The Gold Standard mine In Belr Bay has been idlo aince Karch 31, 1840. The property is still under lease to John Folwarzny who is awalting tine delivery of a new Dlester concentrating table. He erpeots to resume milling sometime in June. A total of three men will be employed. A short ingpection of the glory hole revealed ore on three facea,

iA amall blook of ore, lylng rathar flat, is located betwen the largo

if glory hole and the east glory hole. The following is the total amount mined and milled at the Cold Standard during the years 1938, 39 and 40 lo to data:

U Men Tons Tons

Year Mmployed Mlned Millod* Gross Returna 1938

3

1939 2 937 750 472

1940 to

Mar. 31

\section{3} 578

578

$\frac{103}{1,618} \quad \frac{83}{1,305}$$$
\$ 2,502,43
$$

$$
1,479.78
$$$$
\frac{660.00}{4,642.21}
$$

*Approxlmately ore-fifth of tonnage minod was gorted out at intl.

Kay 30 - Visited Anne Mine prospect.

The Anne Mine prospect consists of a group of $81 x$ claime; namely, Anne, Jenny, Anno Nos, 1, 2 \& 3, and Anne Extension, oovering the old workings of the Anne prospect, loceted south of the Gold Standard and one and one-half mlleg laland from Helm Bay. This claim group is owmod by E. W. Egtrot, Olaf Olaon and R. Knuckolls of Ketchikan. 
Levelopment bes been intermittent during the winter and spring with two men employed, end is confined to drioing a crosscut tumnel at an elevation of 700 peet to cut the Anne vein at a point 212 foet bolow the aurface outorop in the vicinity of the Anne shaft. This crossout tunnel measures to dete 129 feet. A total distanos of 168 feet is required to cut the Anno veln.

A mineralized zone, which outorops a few foet above the tunnel In a small draw, was out in the tunnel betwen polnts 45 to 60 feet from the portel. This zone oonsists of minerelized gresustone sointst wh th narrow irregular quartz f1llings. The zone etrikes N. $270 \mathrm{~W}$. und has a 50 to 550 dip to the northeast. Due to folding, the schletosity verles is the tunnel consiarerably.

Thre日 ohannel samples taken in the tunnel acrose this zone, a total diatance of 15 feet, and eive-foot chandel gamples, gave the following results:

Bample 809, hangwall aoction taken at right engles to dip gave 0.26 oz. All, 0.50 Oz. Ag. $0.70 \mathrm{oz}$. Ag. Sample 010, middle section next to 809 geve 0.06 oz. Au., $0.20 \mathrm{Oz}, \mathrm{Ag}$.

Sample 811, footwall seotion next to 811 gave 0.28 oz. Au., A oonverted auto motor is uged as a compressor and a jeokhamer
i. is mounted and used for drifting. A newly constricted oabin and necessary $\sqrt{6}$ shods are situated below the tunnel.

Since a hlgh grede pocket hes been reported to have been mined from the anne shaft, 1 t will be interesting to follow this development efter enoountering the Anne rein.

The Ione Jock prospect, located above the Anne prospect, is held by Frnegt Steers and assoolates. Asseasment work cone1sting of several outs and 17 feet of underground development wes done in the tunnel this last year. In the tunnel, which is a crosscut below the Lone Jack vein, there has not been sufficlent development to out the voln. Before muoh oould bo determined as to values on this vein, it will be necessery to blast fresh faoes in the old cuts, as in their present condition, conslderable of the mineralization her leacled out, lestIng almost barren quartz and solist. Also, outting the rein in the crossif out turnel wll help oonsiderably in determinlng the contente. 
Located halî a mile above the Anno prospect and two miles from the beech, west coest of Helm Bey, a disoovery of gold quartz pres made by Jack killer wilo hunting in 1930. Th1s property is now bnown as Millex Ledge and lode claims, and conelsta of tbree lode claims on the alviae between Hejin Bay and smuggler Cove dralnages and one clalm on the beach at HeIn Bay. The property is now owned by R. Novatney and Mrs. Osoar Holland of Ketchican, Alagke. The showings oonsist of two narrow flat-lying veins 500 fest epart $\nabla$ ia trald, on the top of the divide at elevetions of 1380' and 1500', respectively. The only vein of any importance is the lower vein. This vein is exposed a distenco of 50 feet along its strike. Its strike is N. $42^{\circ} \mathrm{E}$. and 18 folded on dip Wh the rake direotion wast, varging from 28 to $300 \mathrm{sW.} \mathrm{Two} \mathrm{cuts,} \mathrm{one}$ $22^{\prime} x 15^{\prime}$ and the other 10'x15', expose the veln at each end and the outs are 20' apart. In out No. 1 on the northeast end the vein was followed down on the rake which shows a flat $S$ fold. The width varies from I2" to $15^{\prime \prime}$ and conslgts of bended and alightly minerailzed quartz.

(1) Throe channel samples were taken across the vein in the bottoin

Vo the out whlch gave the following results:
Semple 812, NW, ond of cut No. 1, bottom Bcrose banded quartz, 15", 0.02 02. Au, , 0.70 02. Ag. $0.70 \mathrm{oz} . \mathrm{Ag}$.

Sample 813, Center of out No. 2, bottom 12*, 0.08 oz. All.,

$\gamma^{U}$ Samplo 814, SE. end of out No. 1, bottom 12n, 0.01 Oz. Au., $0.80 \mathrm{OZ} \cdot \mathrm{AB}$.

ulu

Cut No. 2 exposes the vein over 1ts length to the southwest end where the veln dipe under a mantle of glacial graval. The footwell 18 considerably achlited and slightly mineralized. Both walls of the vela consist of the greenstone schlst formation vitich rielkes ur the country rock in this seotion.

Sample 110. 8.5 teken from out No. 2, conter, across $10 "$ of banded quartz, gave $0.36 \mathrm{oz}$. Au. and $0.50 \mathrm{oz}$. Ag.

Sample 816, cut No. 2, was taken across 6'2" of mineralizad schist on the footwell ci the veln, and gave only a traco in gold and aliver.

A hand-made tro-stamp mill pras erected on the claims below out No. $I$ in 1936 by $T$. Flunket and MeDonald. This wes operated by a smell water wheol. A total production of \$I6 in gold was reported. Last year Novetney packed one ton of ore to the Cola Standard mill. Thirty dollers in gold was obteined and 100 pounds of concentrates thet assayed $\$ 52$ in gold per ton. 
Lies 31 - Visited Alta claims and property of Alaska Cold Mountain lifnes, Smuggler Core.

Two Lode claims known as Alta No. 1 and Alta No. 2 are located on the south slope of Gold vountain and along the Heln Bay-Smugeler Cove trall at a polnt one and one-fourth miles from the head of smugeler Cove. These two claims are held by J. Locken and W. A. Armola of Ketckiban. This property was formerly korm as the Meadows and ves discovered by R. Knuokolls of Ketoh1kan.

At an elevetion of 620 feet a tunnel 35 feet 6 inches wes ariven et $a n$ early date to cut $\theta$ silicleied and mineralized zone in Breenstone schist. Two feet of quertz and calcite stringers in e folded zone show in the face of the tunnel. A chennel sesay was reported to heve given returns of 70 conts per ton $1 \mathrm{n}$ gold at thie point. In the cut above, vilich is 12 ' $x 20^{\prime}$ and 40 foet above the tunnel, e two to four inch quartz veln cuts dow through the face of the cut and the slifclfied zone. This Cif small vein contains risible free gold and higb assays have been reported. Assays of the silicifled zone in the greenstone schist were reported as low. The schlstosity of the greenstone sohist strikes N. $20^{\circ} \mathrm{V}$. end the - dip is variable to the west. The zone eppears to have a rake to the SW. Thus tho tunnol belor, driven in a nortberly a1rection, cuts only the vi footrall of this zone.

This years assessment work was oonfined to a quartz cropping, loostod 200 feet northeset of the Alta or above tunnel. Th1s showing consists of a cut 60 feet in lengtb between elavetions of 760 to 820 fert. This is a paraldel zone to the tunnel zone, striking N. $15^{\circ}$ Wo end has $a$ vertical dip. Smell pitte lenses of quartz are inserted as independent bodies in the banging rall of the zone. Narrow seans of purplish to bluleh quartz, some nessuring up to one inch in width, were noted throughout the zone. Thls type of quartz appears to be of a later generstion, and is an unusuel and uncommon occurrance for this region.

Sample 817, In the upper out, taken 20 feat up from the bottom, gcross a 12-inch quartz lense, gave returns of $\$ 10.50$ in gold and 77 cents in silver.

Sample 818, taker in top of upper cut across 21 inches of quartz gave returns of $\$ 2.75$ in gold and 49 cents in silver.

Sample 819, taken in upper cut, 20 feet down from the top across 3 feet of mineralized echiat and blulsh quertz stringers gave $\$ 2.30$ in gold and 49 cents in silver. 
The property of the llakk Gold Mounteir kines, Ltd. vas under development last year until November 18 , i935 whth a crew of six men. since then one and two men have been malntalned on the property doing ctrajl work. During development last year a totel of 448 feet of crose$\therefore$ out, 25 feet of drift and 12 feet of raise was driven. The greater

" portion of the crosecut was off the main tungel level to the wegt vein. Here a schlsted and siliclfied zono was cut from wilch across the certer

$\because 4$ feet an essay of over $\$ 5$ in gold per ton was reported. This wes the

extent of the ore pound. A mill bullding 32'x38' was partly congtruoted.

1.M. B. Bradford reporta the company has purchased a 4 'z6' Meroy ball

y mill, faw crugher, tablo and rlotetion colls. This machinery has not, however, been shlpped to Alaska. The compeny is under 1nvestigetion at the present time by the SEC. and reports were to the effect that the mine is to undergo an examlnation by the Comolssion.

This year the Thorne Arm properties are 1die with the exception

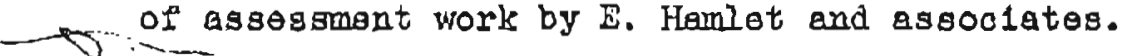

$\mathrm{C}^{5}$ In the Hyder distriot the only active development reported wes $k x+11<-4$ $0^{\circ}$ of the Biferside. This property has been optioned by a man by the name
$\mathrm{S}^{\circ}$ property and expects to dovelop and operate the mill. property and expects to develop and operate the mill.

June 3 - At the request of Mr. B. Libo of Ketchikan for advioe as to whether or not to leaes erom the Department of the Interior on $a$ royalty basis three equare miles fuland from Nadzahes Cove on the east side of Anrette Island, aeveral outcrops of a promising quartz vein were examinez. Apparentiy Mr. Ilbe has been offered the first ohenoe for a lease of this ground by an official of the Interior Dapartment. Terms, r conditions, and stipulations are as yet unknown by him. The outeropa,

$\because$ which show soattered spocks of gold, were disoovared by Mr. Ilbo in 1920. - During the above year two clalms were staked; namely, Lane Molf Nos. 1 and 2. He later attempted to expose the showings, but was notifled to cosse operations.

The outorops are located between elevations of 250 to 500 feet and one and one-fourth miles inlend from Nadzaheo Cove. They consist of several quartz outcrops or lonses in a highly schisted and fractured bend of greanstone between two phyllite bands. The numerous soattered quartz lenses and bunches appear to be directly off the ond of a small sranite or diorite tongue whicb joine the maln mass to the south. In tracing the zone to the north the quartz bodies gradually become loss and a vein forme on the hanglng wall of the greanstope band in contact with the phyllites. 
This vain was traced by float and outcrop north for a distance of 2200 feot. The strike $18 \mathrm{~N} .30-40^{\circ} \mathrm{V}$., and the dip rerled from 26 to $28^{\circ} \mathrm{NE}$. The quartz croppings show visible gold in several localities. The mineralization generally is waak, however, by blasting into the eurface quartz, a creater ratio of minerelization could possibly be obtained. With the small amount of vialble outcrops and stripping done, and only one outcrop exposed to show the nature of the ore, it is only a guess as to the possibilities of the vein making a mine. In fact only in two places could a fair ohannel sample be obtained. Samplo 820 mas taken ecross the vein width of 9 feet in the cut 2200 feet north of discovery, Don the shore of a lake at the foot of Bush Mountain, El. 250 feet. This Ysamplo gave returm of 98 conts in gold and silver. The veln here containg a greater amount of pyrlte then at discovery where gample 821 was taken. The presence of considerable barlte was noted in this cut, and

sthis mineral appeared to be lecktng in the outcrops near discotery.

S-Semple 82.1, taken across discovery out $7 \cdot 8$ "geve returns of $\$ 46.06$ in

'gold and silver. The quartz is Presh, white to dark blue in oolor,

1 and contalas small grantitc and achiat inclusions wh a considerable emount of l1ght silvery nica contained mainly in the fractures. A largo sample is on display in the Juneau office. It may be stated that, with the indications as observed from the number of outcrops, this prospect werrante development to the extent of determining the amount and value of the ore. This information could be most economicaliy obtained by diemond drilling due to flat dip. Then, whth the knowledge galned, and compared with all terms and oonditions of lesse, oould a deolsion be made in regard to leesing from the Interlor Dopartment. Th1s was the advice given to Mir. Libe.

June 4 - In compeny with Kir. U. S. Rugh, the writer prooe日ded to $k x-19-3$ the Flagsteft mine. It appears that kir. Rugb has been studying this property and the surroundine country, for some New York intereste, who are epparently at present heav1ly interested in the riagstaff mine.

The Flagstafs Mining Company has an expenditure to date of $\$ 160,000$. The returng from ore mllled and concentrate melter returns have only been a fow thousand dollers, ${ }^{*}$ on which a ten per oont royalty hes been pald the oxmers, and nothing has been paid on the original

- purchase price of $\$ 150,000$. The royalties do not apply on the purchage price, however, the company may continue to mine as long as royelties of (ten per cent of the grose returng are pald, and the ralne operated nine

inontha per year.

Apparently, ance the mine was not proaucing a profit and the expenditure of more oapital wes noeded this sprinf, the New York interests sent Mir. E. M. koCurdy, engineer from San Franclsen, to make an examinetion end investigation. This examination, which was wholly for the

*For exact figures on production and expenditures, costs, etc. refer to copies of cost sheet, etc. by kiccurdy on file. 
purpose of. doternining returns on already invested capttal, end strengtheneț by the numerous mistakes in mining, milings and the expenditure of develop-j ment capital, gave the sbove-mentloned recormendation, whiob has resulted in closing operations since that time. Thare was considereble coment In the report as to the insoouracy of the mine assays, the mill operation and the unaccounted-for $\$ 43,000$ of the total sun apent. The cost of this exemination was reported emounting to over two thousand dollers.

No doubt the New York 1nterests have more knowledge and a better senge of fudgment as to the property and have declded on the present examination by $M$. U. S. Rush. With these conditions known and a falr kmowledge of the property, the wer discused the whole situation vilth var. Fugh. Besides glving him verbally all the information regarding the property that was known, the writer ment over the greater portion of the workings with him. It was pointed out to him the inaccurecy of charging all development costs on a few months of poor rilling, and the emall amount of development, against the possibilitles. Further, I actuelly showed him where in the last 50 feet of tunnel work the orirt turned $15^{\circ}$ to the south and followed a rein phich leares the diabage dike and goes into the footrall, and contains no values, while ore shows in tho dike on the ourface further (in the mountain. This fact was not mentioned in Mccurdy's report. $\checkmark$

While there are many angles and considerable could be valten concerning the causes of the present conditions, at least the greater portion i. of these conditlons would rot have come about, had they taken th1s depart-

ment's adrice and obtained a capable mintng men in the beginning instead of

(trying to operate among themselves. Who these New York interests are, the (foriter ald not learn. However, the interesta ere all hela bf a small group of individuals and no stook has been sola to the publio.

In the mine the tunnel has been advenced to a total length of 1120 feet. The tunnel length was 485 feet when the conpeny took option July 28, 1937. Durlne the last jear's work, three additional raises bave been oriven to helghts averaging 55 feet. This makes a total of six ralses. A 50-1oot Winze pres sunk on the vein lest winter at a point 880 feet from the portal. Quertz shows down its ontire depth ranging fron 18 inches to nearly 3 feet and was reported es good ore. At a point 900 feet from the portal a crose-veln wes encountered which contains only amall velue日, and beyond which no velues were encountered in the tunnel on the main ve1y. (Note klocurdy's map of workinge).

Safety conditions in the mine are good. The raises are timbered and laggod, ladders good, and the drift timbered occasionally. The Winze 18 not timbered, but bas good valls and stulls on the rootwall contain ladder and bucket guldes. 
The adaltions in the mill consist of another 100-ton ore bin, 3x4' Morse Bros. ball mill, Dorr olessifler, and amalgam plates. The Caterpllilar motor has been replaced with a $90 \mathrm{H}$. P. Goneral Motors diesel. An Ingersoll-Rand type 10 - $440 \mathrm{cu}$. ft. double-cylinder compressor hag been installed. As a reault of both milla, the compressor and 831 other movable milling equipment being povrered by the diesel, it has been overloaded and has glven conslderable trouble. The road was completed last sumer from the lake to the mine, and trucks now run from the mine to the beach, with barging acrose Karta Lake on a powered raft. A total of four men are at present meintained on the property.

June 5 - Visitea Kasaan Gold Mine on Harris Creok. The faulted

block of ore, formerly referred to as the Freo fold or cross-vein on the Resarn Gold property, has been definitely proven to be a faulted segment of the hangine well or upper vein of this property. The vein in place was discovered underground by following the faulted segment to the northeast, ag was suggested two jears ago. The fault was of a hinge type of recent orlgin and due to grevity. In following the faulted eegment northeast the veln narrowed, turned a $60^{\circ}$ angle and the bottom extension A. was on a normal strike of N. $10^{\circ} \%$ and has a dip of 300 to $40^{\circ} \mathrm{NE}$.

P. Thus with the lenown position underground, this wes projected outilde on

i the surface and by projecting the strike down the slope to the mill level, a new tumnel was started and the veln was encountered in 20 fert from the portal. This tumel portal 18260 feot from the mill and 35 - foet vertioally below the working tumel. The mill tunnel is in only

i working tunnel since lagt year. Last year durine a four-month milling ( period a total of 1,000 tong of average $\$ 12$ per ton ore was milled. Thie year Dewson expects to mill 1200 tons of about the seme grade of ore.

Since last year a new $15 \mathrm{H}$. P. General Motors alesel notor has been ingtalled in the mill, which is direct-connected to a $10 \mathrm{~K}$. W. generator, which furn1shes power to the mill. A new Denver squipment 8xl2" J1s hes been installed and handles the table tallings and a much better saving was reported. The to the jucreased efflclency in the mill, It is mu with the labor of one man. Thus the labor required to operate one shift in mine and mill, is three men.

The present status of the mine is an approximate 5,000 tons of ore blocked out in the faulted block ready tor stoping. This next winter developrant will continue on the mill level tunnel on the ore in place and will incresse the reserve. However, by adding the costs of now equipment and development costs onto the mining and m1l11ne costs, it has amounted to the total recovery from the ore.

A new aerial trem 2,650 foet in length of $3 / 4$ " cable and $5 / 16^{\prime \prime}$ runing cable, powered by a $3 \mathrm{H} . \mathrm{P}$. gas onglile, extends from the mill to the valiey flat of Harris Creek. 
June 6 - A few bours were spent on tine Cracker Jack and

$$
32-19-72
$$

Hope prospeots on the return on foot to Karte Bay.

Last geason several surface outs ware put down on the two parellel veins on the Craoker Jack property. In these cuts both the hanging well quartz and footwall quartz with the graenstone dike in the center is exposed. In following the sasays of samples taken by the MCWhekens in these cuts, it wag noted that the pootwall quartz containgd the hlghest values. The footwall quartz is very narrov, averaging possibly 12 inches and assay reports showed up to 14 ounces of gold. The surprising feature is that at the polnt where the 14 ounce semplo was taken, and in fact all the other bigh assay points, there was no fres gold showing. Ploked samples were taken and testa for tellurium ware nade with negative regulte. A silvery bright metalile mineralization was notad. Anothex factor noted on the assay returns was that, by weight, almost an equal amount of silver and gold was obteined. The l4-ounce gold assay also gove a 16-ounce silver assay. The values in the hanging wall quartz were low. The omers were advised by letter to oontinue

() the surface trenohing and stripping.

The Fope mine operated last year by fricson and Locke is now $k x-1 ;-7 c$

A being operated by the owner, B. LeBrant. It was reported that a total

production in four months last year netted the lessers a total of $\$ 5600$

In gold. The ore everaged over $\$ 50$ per ton and was mined neer the

$\therefore$ aurface in the top of the old stopes. Very littlo production is expeoted

this year.

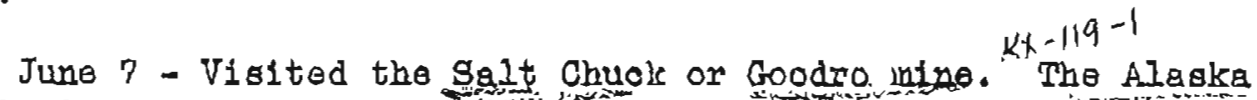
Gold Metals Oompany has beon operating continuously sinoo last yoar in the rine with mill operation intermittently. A total of 900 to 1,000 tons is milled monthly which ranges in value from $\$ 3$ to $\$ 5$ per ton in gold and pelladium. The development work in the mine hes been mainly stoplag with ralser. A total of 1300 feot of ralsea have been driven 8ince 1935. This stoping has been along the edges of the glory hole which has beon onlerged considerably. The costs of mining and milling were reported as avereging $\$ 1.60$ per ton. A total of four men are employed, working only one sulft with a total of 60 men shifts in the rine and 12 to 15 shifts in the mill per month. The amount of koow ore in the vioinlty of the glory hole consists of 30,000 square feet. The depth of the ore is unimow. In all the outcrops on the coodro property. It has been estimated that a total of 200,000 square feet containg ore. It wag noted that all minine is being carried on with ary machines. Two days after the uriter's vialt, the property was examinod by Rr. Richeison, formerly of the Kennecott Copper Corporation. 


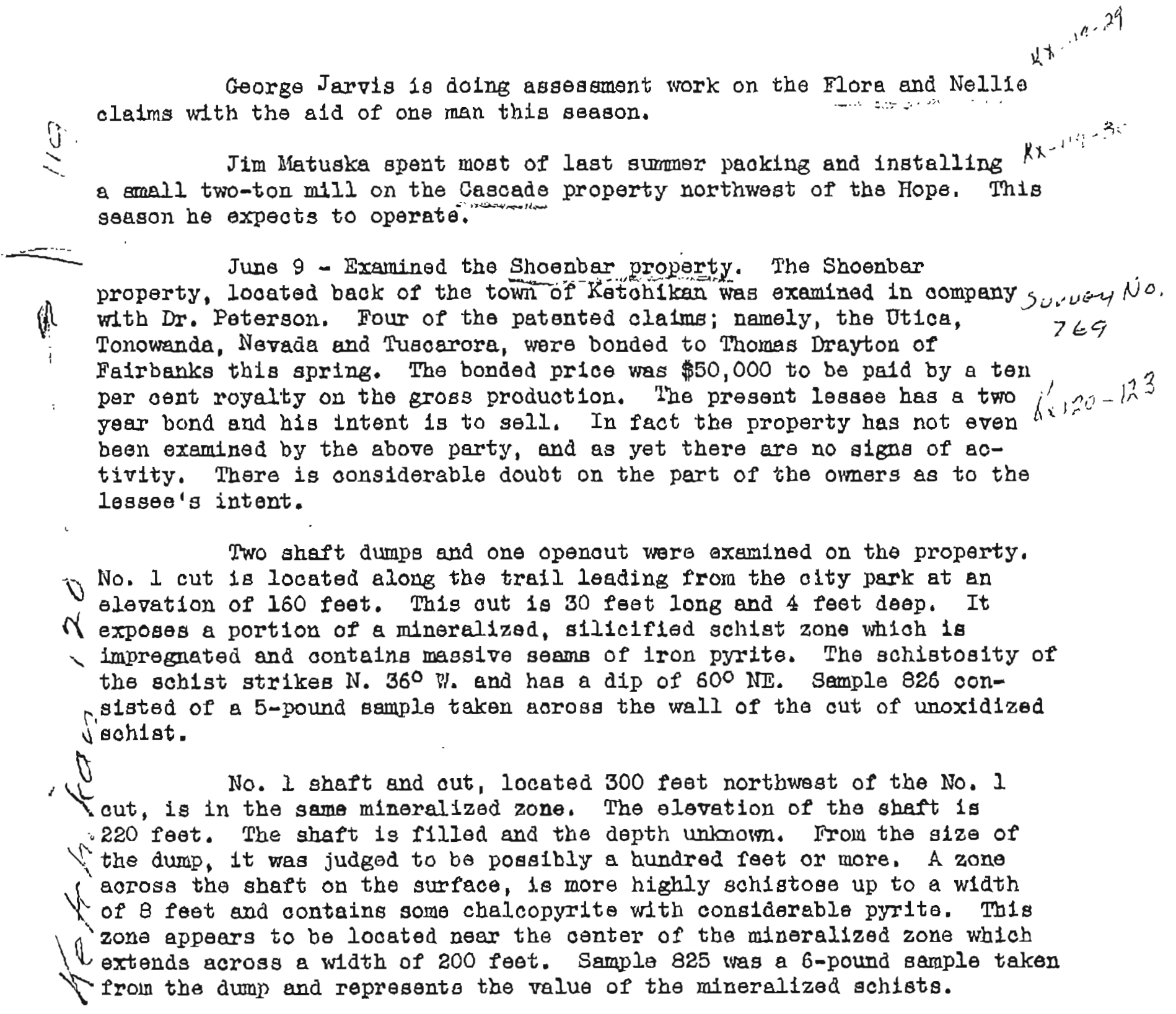

No. 2 ghaft is located 500 feet north of No. I shaft at an elevation of 210 feet. Thls has a reported depth of 30 foot. The formation is less solliatose here and ranges frou greenish to bluish in color. The amount of fron pyrite is greater than contalned in the sohists at No. I shaft. The emount of associated chalcopyrite 19 less at No. 2 shaft. Sample No. 824 was taken froin gathered pieces on the shaft dumy whlch contained nearly massive sulpbides. This samplo will represent the approrimate value of a sulphide ooncentrate made from this ore. 
Sample 823 wes a 6-pound sample gathered off the dump, representing the

. grade of ore. Thus, if sample No. $823 \mathrm{wth}$ a greater amount of sulphides

$\therefore$ fom No. 2 shaft givas lesg values than amplo 824 from No. 1 shaft with leas mineralization, it will show that the amount of gold is not in proportion to the iron sulphide content. F w1ll also show thet the gold content lnoreases with the pressure. A fow years ago an attempt was made to oyanto the No. I shaft dump. Th1s process constated of throwing the dump mun mick into cyerido tanks. One shipment of precipitete was shlpped through the bents. This precipitate wes reported as only containing a trace of gold.

L. U. S. Fugh made a geological map of the Shoenbar property, along with a report several yoars ago. Thls we sald to be unfarorablo.

June 11 - Kotchtkan to Wrangell.

Jack Anderson and Carl Thygenson are prospecting in Sradilela Canal, southeast of irangell. They report having found severel occurrenoes of a sllver-lesa ore in greenstone and limestone, the latter occurring as roof pendents in the bathollth. The discoveries, as they reported them, are not of gufflojent size to warrant an examination. They further report the occurrenoe of atannite in the vicinity of a granite stoak on tho north slde of the dafil near the head. They expoct to prospect this stook furtier for esssiterito and if found will send samples.

June 1R - VLalted E. Brown and Dr. A. B. Kearsloy propertles, Pats Cre日k, Vrangell Islend.

Trwin Brown has a gold prospect wilch he disoovared in 1935 on the Obaidian claim looated 1,000 foet north of the mouth of Pats Croek on the wast sioe of Wrangell Island $12 \mathrm{mlles}$ south of vrangell. The showing consists of a rook out at the face of $a$ low bluff on the contaot of grantte and ghale or alate sediments. The oontact is broken and Irregular with numerous lerge inclusiong of alate whthin the grante. The contact phese of the granite is pegmatitic in nature cozsleting of segregatione of white to pink seldapar and whits to clear guartz. A pyrite mineralization wag noted in the contact phese of the granite and in the hardened slates. A few small seams were noted in the granite. Brown reports assays up to $\$ 150$ in gold per ton from material taken from the seams. Assays of slate and granlte were reported as oonteluing very low values in gold. Several reference samples were taken for inspection.

In 1934 Brown found another similar showlng on a simllar contact on the north bank of Pats Creek, one-half mile up froin the mouth and 40 roet below the Government trail. In this abowing he laterested Dr. A. B. Kesrsley of Virangell. Several claims were staked and the alscovery claim is boom ag the Serab Anma claim. This discovery showing 
constitutes the entire discovertes and showngs on the group according to Brown. A cut into the bank 20 feet wide was done by Brown. Th1s cut reveals a contact of granlte and black slate on ar irregular contact whth inclugions of slate in the granite, and soll 1rregular quartz feldspar velns into the slate. An esst-west post-shear bes gchisted

Nand altered 5 fest of granite along the contact. This ghared and soft

- cantie is al1ghtiy nineralized. Brown clalms that from samples of this of sheared granite Dr. A. B. Kearsley obtalned the reported nlobium, radium, if pletinum, gold and silver. Brown further claims his assays showed a gold 5 and allver value of only $\$ 2$ per ton. Ir. Kearsley was reported to have 3
2
2
3 concelved her 1de日 of niobium in en attempt by hereelf to extract gold from the rook by bolling in acid. Durting the process surgicel instruments were used to handle the rock ple0es in the acid, and a disintegration of portions of the instruments and the clotbes she was pesring took place. As a result, samples were reported to have been sent outalio for analysis where the above elements were discorered.

A display of the grenite wh all phases of oontaot inoluding the black slate was brought to the Juneau of 100 .

Brown has no falth in his flndings and reports no work done on the oroperty since 1937.

$$
k x-119-1.50
$$

June $15 \& 16$ - Upon the report by Ernest Steers of Belm Bey that numerous small galens stringers with high sliver valueg occur on the top of Pin viountaln on Coronation Island, a delayed trip was nade to the

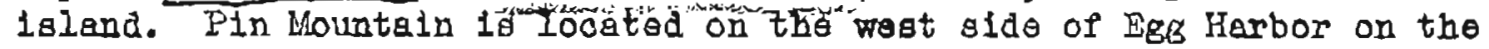
northwest end of Coronation Islend. Mr. Steers was engaged by the Coronation Mining Company in 1903 to transport several tons of galena ore from ggg Harbor to shipping points. The examination wes made to exemine these ocourrences and the old workinga of the cerenatton uining Company. Pin kountain consists of limastone varying in color from gray to 1. bluigh gray, and eeveral bufe to yellowlah hues. The mourtain is bluffy on the $\mathrm{Rgg}$ Harbor slde, steep with timber line at 1,000 feet. The Iimestone beds have a northwest-southegst atrike and are tilted to the west. Several cross 118 sures cut the ilmestone at a strike varying from

- WN. 50 to $70^{\circ}$ E. and with noarly verticel d1p8. Severgl of these flsgures contain narrow dikes of greengtone. Both the greenstone dikes and the walls of llmostone have been altered both by solutions and some movement. A slight mineralization of pyrite was noted, and considerable 1ron oxides with a Iittle associated secondary lesd in pots along the sissurea. occesionally bunches of nearly puro celcite conteining a very slight mineralization were noted. The dikes appear to be fissure fillings of lava and while the major lead showing mined was alongside a greenstone dike, they are not believed to be geneticaliy related. 
Three tunnels and one gmall glory hole comprise the old workings of the Coronation lifing Company. The lower, or No. 1 tunnel, located at an elevation of 780 fest, was started on the footwall side of a fisgure in a steep ravine. This fissure is in ilmestone striking iv. $70^{\circ}$ ․․ and oonteing calcite with a ifttle quartz in bunches and a weak mineralization of iron pyrito and galeng. The tunnel was ariven on a bearing of S. $73^{\circ}$ W. for 40 fert, thence S. 450 W. for an additional distarce of 31 fert. This put the froe of the tunnel furtber into the footwall than the portal. The oalolte bunchos are apparantly large for at a polnt 40 foet from the portal some calctiv or the north well 18 ahowing. It contains a Ilttle Iron pyrite, but no lasd is shoving.

The upper tunnel, elevetion 1020 feet, on $a$ level with the upper terminal trem tower, whlch is still atanding, has been covered wh silide meterial and is inaccessible. The outoroppings in the fissure above the turnel show a 4 foot ereenstone dike. This dike is soft end highly deoomposed on the surface and conteins conalderable iron oxides. f. Small amounts of pyrite, secondary lead and gmall amounts of galema vere Jobserved along the vialls mth calosto bunches. While tho leed and Iron $\therefore$ minerals are partly a replacement of the limestone, the small ore lensed ' which were apparently mised in the tunnel below were apparentiy more of a filling in an open risaure along with oalcite.

Below the upper tunnel et an elevation of 820 foet, end loosted 400 feet below, a midale tunnel was ariven along a dike for 400 feet, thenoe a 60-foot crossout to the north, ich cuts three mell dikes, thence the arift oontinues, but is cared. No atoping or ore showe in the uncered portion.

A small glorg hole is located 300 feet southeest of the midalo tunnel at an elevation of 800 feet, end alons the trall. Thls glory hole Is 12 feet long, 10 feot deey and 5 feet wlde. A few tons of bigh grado were mined and the ore occurred as a kidney in blue limestone and is not assoctated with any nearby dike.

Directly bolow the upper tunnels, and at the base of a $300-$ foot bluff on the begch, several limestone caves extend 200 to 300 reet into the bluff. In one cave, 250 feet from the moutb, ereenstone alke was found on whlch a 60-foot tumnel has recently been ariven. Large bunches of calcite occur on the tunnel walls, but no evidence of lead was found.

Thus there small lead deposits mined by the Coronetion Mining Company were formed in openings in plsgures, some of whioh had been promilled with lavas and some openings formed by movement. The deposits are of supergene origin and occur in part whth secondary mineral.s. The galena stringers on the top, after conslderable invegtigation, were not found. 